\title{
A RELEVÂNCIA DA ADVOCACIA-GERAL DA UNIÃO COMO INSTRUMENTO PARA A SATISFAÇÃO DO INTERESSE PÚBLICO
}

\author{
JOÃO CONRADO BLUM JÚNIOR*
}

1. Introdução - 2. Posição Institucional da Advocacia-Geral da União e a necessidade de um avanço paradigmático - 3. O interesse público vislumbrando-se os aspectos primário e secundário - 3.1. Análise de relevantes atribuições do Advogado-Geral da União - 3.2. Notícias sobre a atuação da Advocacia-Geral da União e de seus órgãos como exemplos práticos de que há viabilidade na busca dos interesses primários - A) Advocacia-Geral da União edita súmulas que beneficiam contribuintes do INSS e da Receita Federal - B) Advocacia-Geral da União economiza R\$ 2,9 bilhões aos cofres públicos em seis meses - C) Procuradoria Regional da União da $1^{a}$ Região, órgão da AGU, atua e Justiça decreta arresto dos bens de Luiz Estevão - 3.3. Exposição esquemática da atuação da Advocacia-Geral da União na busca incessante dos interesses primários - 4. A pugna pelo desenvolvimento gradativo da Advocacia-Geral da União-um esclarecimento contextual - 5. As atividades da Consultoria-Geral da União em face da observância dos interesses primários - 5.1. Uma breve análise de pareceres da Consultoria-Geral da União que se consolidaram como jurisprudência administrativa - 6. A razoabilidade na atuação da Advocacia-Geral da União - vista sob a ótica do interesse público - 7. Conclusão - Bibliografia.

\section{RESUMO DA MONOGRAFIA}

Este trabalho analisa a atuação da Advocacia-Geral da União, destacando-se o ponto de vista da necessária satisfação do interesse público. Inicialmente, discorre-se acerca da necessidade de um avanço paradigmático no que concerne à relevante

* O autor é acadêmico do $4^{\circ}$ ano de Direito da Universidade Estadual de Ponta Grossa - UEPG (Paraná) e estagiário bolsista do Ministério Público do Estado do Paraná. 
atuação da aludida instituição. O foco primordial do estudo é a diferenciação, de acordo com a doutrina de Renato ALESSI, entre os interesses públicos primários (interesses públicos) e os interesses públicos secundários (interesses secundários). Comentam-se recentes atuações práticas da instituição, tendo-se como norte, a busca incessante, mas com razoabilidade, pelos interesses primários. Conclui-se, ao final, que uma atuação da Advocacia-Geral da União voltada para a satisfação do interesse público, observando-se o interesse da União, é perfeitamente possível e desejável, devido às consequiências benéficas que podem ser obtidas para a coletividade brasileira.

\section{Introdução}

A Advocacia Pública abrange, segundo a Constituição Federal de 1988', a Advocacia-Geral da União e as Procuradorias dos Estados e do Distrito Federal. Neste estudo, houve a preocupação em deter-se unicamente ao aprofundamento da noção de interesse público na relevante atuação da Advocacia-Geral da União, instituição criada pela referida Constituição, que visa também, em última análise, a concreção da justiça no Estado brasileiro.

Hodiernamente, a sociedade vem cada vez mais clamando pela satisfação das inúmeras necessidades básicas de, efetivamente, todos os seus indivíduos, já que o processo de empobrecimento e exclusão social da maior parte da população vem gerando nefastas injustiças, o que deve levar os órgãos públicos que buscam, de alguma forma, a garantia dos direitos fundamentais insculpidos na Magna Carta de 1988, como é a Advocacia-Geral da União, a terem uma atuação mais concreta na perseguição primordial do interesse público².

$\mathrm{O}$ interesse público é um dos balizadores supremos das atividades estatais, caracterizando-se como o grande norte da administração pública para a efetivação plena dos anseios básicos da população excluída. Pois no momento em que houver, em todas as esferas do Poder Público, a consciência social mínima necessária para o exercício de tão relevante mister, certamente, as injustiças corriqueiras serão tidas como imensos afrontes ao interesse público, que nada mais visa do que a garantia dos direitos fundamentais de uma sociedade pluralista e democrática.

Este estudo monográfico almeja demonstrar, de forma clara, a importância de uma atuação comprometida com os princípios da supremacia e da indisponibilidade do interesse público por parte da Advocacia-Geral da União, observando-se também o princípio da razoabilidade, para que as mazelas sociais possam gradativamente ser expurgadas do seio social, contribuindo-se assim para um melhoramento substancial das relações entre Estado e sociedade. Visto que, o Poder Público, como bem salientou Diogo de Figueiredo Moreira Neto, "é cometido ao Estado para que, assim

1 Artigos 131 e 132.

2 Sobre o qual está exteriorizada, no item 03 , a concepção doutrinária que mais se adéqua ao propósito desta monografia. 
concentrado e institucionalizado, lhe seja possível prosseguir os fins para os quais se o criou: a satisfação dos interesses da sociedade." (MOREIRA NETO, 1991, p. 16)

\section{Posição institucional da Advocacia-Geral da União e a necessidade de um avanço paradigmático}

A Advocacia-Geral da União, como função essencial à justiça, deve sempre se pautar, em sua atuação, pela busca incessante do interesse público ${ }^{3}$, não devendo manifestar-se, como ocorre atualmente e na maioria dos casos, estritamente como um órgão "longa manus" ${ }^{4}$ da orientação política albergada pelo chefe do Poder Executivo Federal. Já que a Advocacia-Geral da União está acima de discussões políticas, as quais, em grande parte, acabam se sobrepondo ao interesse público, isso porque o assento constitucional dado a essa instituição não deixa ressaibos de dúvidas de que a representação da União nos assuntos de seu interesse está cabalmente vinculada à observância da Constituição Federal e, ainda, daquele.

Não se defende aqui que o chefe dessa instituição, o Advogado-Geral, como os demais membros, precisem atuar com "imparcialidade extrema", visto que isso não é possível, dada à própria natureza legal da instituição, contudo, é possível e necessário que haja uma atuação efetivamente vinculada aos interesses públicos.

Parecendo conveniente expor-se, neste momento, a natureza jurídica da Advocacia-Geral da União que, conforme a Magna Carta $^{5}$ brasileira, "é a instituição que representa a União [sem grifo no original], judicial e extrajudicialmente, cabendolhe as atividades de consultoria e assessoramento jurídico do Poder Executivo", o que demonstra a amplitude técnica de sua atuação e, em razão disso, a importância do atendimento ao interesse público. Ao representar o interesse da União, a Advocacia-Geral da União precisa aferir preliminarmente qual é o principal aspecto do interesse público naquele caso, ou seja, quais são os benefícios que certamente acontecerão para a coletividade diretamente envolvida, que pode ser tanto a sociedade em âmbito nacional, como segmentos sociais carecedores de substrato material para imensa parcela de seus direitos fundamentais.

Para que haja um fortalecimento da Advocacia-Geral da União como instituição essencial à justiça, necessita-se muito de uma atuação em conformidade com os parâmetros configuradores dos interesses da União, mas necessariamente arraigada com os fundamentos caracterizadores do interesse público, cujo conteúdo abarca o interesse de toda a coletividade, que se consubstancia na busca em grau máximo possível da satisfação total das necessidades sociais, sempre se perseguindo o ideal

3 Trata-se do interesse primário, como se verá mais adiante.

4 Nesse sentido: FIORANELLI JÚNIOR, Adelmo. - A Procuradoria Geral do Estado como função essencial à justiça. Revista da Procuradoria Geral do Estado de São Paulo, 40, dez., 1993, p. 249.

5 Transcrição de parte do artigo 131 da Constituição Federal de 1988. 
de uma sociedade justa e que não gere excluídos. $O$ interesse na concretização de um ideal, como é a justiça, em todas as suas facetas, é importante na medida em que faz o homem procurar novos horizontes, dando passos para frente e não permanecendo acomodado, estagnado, em face das gigantescas mazelas existentes na sociedade brasileira. Destarte, como consequiência lógica, concretizar-se-á, no cerne do corpo social, o devido reconhecimento à Advocacia-Geral da União, preenchendo-se assim, de forma completa, as lacunas da finalidade e dos motivos para a existência de tal instituição.

Analisando-se a Lei Complementar $n^{\circ} 73$, de 10 de fevereiro de 1993, que é a Lei Orgânica da Advocacia-Geral da União, em seu artigo $4^{\circ}$, onde estão colocadas as atribuições do Advogado-Geral da União, percebe-se claramente a intenção do legislador, escancaradamente no inciso $\mathrm{IX}^{6}$, em fazer com que a Advocacia-Geral da União, em seu agir, atenda, conscientemente, ao interesse público, não sendo objeto de manipulações políticas ou de interesses escusos. Obviamente que não será qualquer tipo de alvoroço social que deverá ensejar sugestões ao Presidente da República, uma vez que os meios de comunicação de massa, muitas vezes, tornam-se verdadeiros insufladores da população contra conquistas jurídicas muito relevantes, o que leva ao afronte do próprio Direito, que é "naturalmente bom", podendo ser "ruim", porém, dependendo-se da aplicação que lhe é dado.

Gilmar Ferreira Mendes, citado por João Carlos Souto, em seu discurso de posse no cargo de Advogado-Geral da União, fez brilhante afirmação:

[...] A defesa do patrimônio público constitui missão absolutamente irredutível à defesa do interesse do Estado ou ainda ao suporte a políticas públicas específicas. Somente uma insustentável hipóstase e distorção da noção de Estado poderia induzir à crença em uma defesa intransigente do patrimônio público dissociada dos interesses de seus constituintes ou mesmo a eles atentatória. A defesa do patrimônio público confunde-se com a defesa da sociedade, constituindo um pressuposto objetivo da viabilidade de toda e qualquer política pública. Dúvida não há, portanto, de que se cuida de escopo em tudo transcendente a contextos políticos e orientações ideológicas. [sem grifo no original] (apud SOUTO, 2001, http://www.agu.gov.br/ce/ cenovo/ce.asp?mnu=3_2\&num=7)

Isso faz reforçar a idéia de que o agir da instituição Advocacia-Geral da União deve conformar-se na orientação que melhor atenda aos interesses da coletividade, através das políticas de desenvolvimento social, que nada mais são do que os interesses da União.

Cunhados, então, os principais aspectos institucionais da Advocacia-Geral da União, vistam sob a ótica da satisfação ao interesse público, o que gera, uma possibilidade concreta de aplicação justa do jus positum, de acordo com as cláusulas

- "IX - sugerir ao Presidente da República medidas de caráter jurídico reclamadas pelo interesse jüblico [sem grifo no original];" 
pétreas da Constituição da República de 1988 , trazendo-se, dessa maneira, a justiça para toda a sociedade, porque justiça social para poucos não é justiça, mas sim um mero controle das massas exercido amplamente e maquiavelicamente.

Essa deve ser a visão norteadora da atuação dos membros da Advocacia-Geral da União, assim como de qualquer outro órgão público, para que sejam alcançados os ideais visualizados pelo legislador constituinte originário e que ainda, lamentavelmente, não foram devidamente agregados por aqueles que deveriam, com mais afinco, resguardá-los, não deixando imperar o "Estado das injustiças" que se chama Brasil.

\section{O interesse público - vislumbrando-se os aspectos primário e secundário}

A noção de interesse público deve ser analisada, segundo a doutrina de Renato ALESSI ${ }^{7}$, sob duas nuanças, a do interesse público primário e a do interesse público secundário. Essa distinção tem grande relevância para que se possa auferir um melhor entendimento sobre a postura ideal, que tanto se peleja desde o início deste trabalho, e que deve arraigar-se ao desempenho das funções pela Advocacia-Geral da União.

Os interesses públicos ${ }^{8}$, tais como enfatizados nas linhas anteriores, correspondem ao que ALESSI denomina de interesses primários da Administração Pública, visto que esses são os interesses da coletividade considerada em sua inteireza. são os interesses maiores de todo um povo, mantidos sob a égide da Constituição Federal de 1988 e do Estado Democrático de Direito. Os interesses primários, portanto, são aqueles que pertencem a todos, sendo de todo o povo, considerado coletivamente, sendo esta a interessante definição colocada por De Plácido e SILVA ${ }^{9}$. Por isso, a administração pública deve pugnar pela vitória social de toda a coletividade, garantindo, primordialmente, a satisfação do interesse primário. Evidentemente que não é uma tarefa fácil de se concretizar, já que necessita de um bom planejamento, principalmente voltado para a melhoria geral das relações em sociedade, observando-se menos o "contentamento" dos Estados estrangeiros nas relações econômicas internacionais, que é um dos grandes desvirtuadores das finalidades precípuas do Estado brasileiro consignadas na Constituição Federal de 1988.

Já os interesses secundários, de acordo com a lição de $\operatorname{ALESSI}^{10}$, são os interesses que a Administração Pública em geral poderia ter como qualquer outra pessoa, isto é, independentemente de sua qualidade de servidor de interesses de terceiros: os da coletividade. Então, esses são os interesses da Administração, que

7 Apud MELLO, Celso Antônio Bandeira de. - Curso de Direito Administrativo. 11. ed. São Paulo, Malheiros, 1999, p. 32.

8 À guisa de esclarecimento, é preciso dizer que sempre e tão-somente quando se utilizar a expressão "interesse público", será como sinônima de "interesse primário" e vice-versa, sendo que o mesmo não vale para a expressão "interesse secundário".

9 Vocabulário Jurídico. 17. ed. Rio de Janeiro, Forense, 2000, p. 661.

10 Apud MELLO, Celso Antônio Bandeira de. Op. cit., p. 32. 
podem ser visualizados, verbi gratia, nas situações em que a administração pública busca gastar o mínimo de recursos e, ao mesmo tempo, impõe ônus imensos aos administrados, gerando uma receita maior para a administração pública, porém sem uma devida contraprestação efetuada em favor da coletividade. Verificando-se, dessa forma, uma atuação que, definitivamente, não atende aos fins precípuos de toda sociedade organizada, que nada mais são do que os interesses primários empiricamente observados.

Pode-se notar, a ser assim, que sempre haverá prevalência dos interesses primários sobre os secundários, já que os primeiros correspondem aos interesses da coletividade, a qual delega poderes aos administradores para que estes satisfaçam aos anseios daquela. Por conseguinte, conforme assevera, em seu Curso, Celso Antônio Bandeira de Mello:

[...] os interesses secundários não são atendíveis senão quando coincidirem com interesses primários, únicos que podem ser perseguidos por quem axiomaticamente os encarna e representa. Percebe-se, pois, que a Administração não pode proceder com a mesma desenvoltura e liberdade com que agem os particulares, ocupados na defesa das próprias conveniências, sob pena de trair sua missão própria e sua razão de existir. (Op. cit., 32)

Sendo que, logicamente, a instituição da Advocacia-Geral da União também está adstrita, primeiramente, ao atendimento dos interesses primários, o que, aliás, é pressuposto de atuação para todo e qualquer órgão público dentro dos parâmetros da ordem jurídica instituída em nosso país pela Magna Carta vigente.

É, de certa maneira, tranqüilo o entendimento doutrinário de que a primazia do interesse público tem status constitucional ${ }^{11}$, parecendo preeminente destacar o inciso XIII, do parágrafo único, do artigo $2^{\circ}$, da Lei $n^{\circ} 9.784$ de 29 de janeiro de $1999^{12}$, que dispõe o seguinte: "interpretação da norma administrativa da forma que melhor garanta o atendimento do fim público [sem grifo no original] a que se dirige, [...]". Coloca-se este dispositivo em razão de utilizar-se interpretação teleológica, salvo melhor juízo, no que tange à busca do interesse público que, realmente, conforme exposto acima, é o interesse primário, objetivo supremo da administração pública como um todo e da sociedade. Destarte, interpretarem-se as leis e os atos da administração pública segundo os fins a que se destinam, leva-se à distinção mais nítida se houve ou não o atendimento aos interesses primários, o que se afigura como sendo um critério razoável para que a sociedade fiscalize os gestores da res pública, a qual, evidentemente, não deixa de ser defendida pela Advocacia-Geral da União.

11 Nesse sentido: OSÓRIO, Fábio Medina. Existe uma supremacia do interesse público sobre o privado no direito administrativo brasileiro? Rio de Janeiro, Revista de Direito Administrativo, 220, abr./jun., 2000, p. 89.: “No Brasil, é certo, não há norma específica consagrando o interesse público como princípio geral da Administração Pública na $\mathrm{CF}$, mas tal princípio ostenta status constitucional, na medida em que consagra uma finalidade indisponivel imperativa da Administração Pública e, por conseguinte, de seus agentes, revelando-se imanente ao sistema."

12 Regula o processo administrativo no âmbito da Administração Pública Federal. 


\subsection{Análise de relevantes atribuições do Advogado-Geral da União}

À luz da abordagem exposta no item supra, faz-se mister, neste momento, aferir-se alguns pontos interessantes da atuação do Advogado-Geral da União, chefe da Advocacia-Geral da União, na busca da satisfação do interesse público, considerado aquele, como se sabe, o mais elevado órgão que trata do assessoramento jurídico do Poder Executivo ${ }^{13}$.

Parece de grandiosa valia uma análise dos principais itens, não de todos, pois extremamente convergentes com o que se propõe neste estudo, do artigo $4^{\circ}$, já citado alhures, da Lei Complementar $n^{\circ} 73 / 93$, dispositivo que delineia as atribuições do Advogado-Geral da União. Entretanto, sem se seguir à ordem dos incisos desse artigo, inicia-se fazendo referência ao já aludido inciso IX $^{14}$, cujo conteúdo procura impulsionar o Advogado-Geral na busca incisiva dos interesses primários, que são os interesses da coletividade.

Outro dispositivo é o inciso $\mathrm{X}^{15}$, do artigo $4^{\circ}$, que atribui ao Advogado-Geral umas das mais importantes tarefas realizadas, nos dias atuais, pelos juristas, que é a interpretação das normas (lato sensu), explicando-se o sentido e tirando-se as conclusões do que se analisa, imprescindivelmente, evidenciando-se, como alicerce norteador, a efetividade dos interesses primários, de acordo com o ordenamento jurídico posto.

Destaca-se do inciso $\mathrm{XI}^{16}$, do mesmo artigo, a atribuição conferida ao chefe da Advocacia-Geral da União consistente em assegurar a correta aplicação das leis, que nada mais significa do que pugnar pela mantença da ordem jurídica, o que coloca a administração pública federal "nos trilhos" conducentes aos interesses primários.

Aferindo-se o inciso $\mathrm{VII}^{17}$, do referido artigo, onde está estabelecida uma atribuição ao Advogado-Geral que, verdadeiramente, tem relevo colossal, já que cabe àquele assessorar juridicamente o Presidente da República, elaborando pareceres e até propondo normas, medidas e diretrizes. Nota-se que andou bem o legislador infraconstitucional ao estipular essa espécie de atribuição ao chefe da AdvocaciaGeral da União, em razão de, havendo uma conduta comprometida com o caráter não-privado da administração pública, se poder, realmente, enfatizar, ao chefe máximo do Poder Executivo no Brasil, os importantes avanços sociais almejados pela coletividade, garantindo-se assim, a satisfação ao interesse público.

13 Artigo $3^{\circ}$, caput e parágrafo $1^{\circ}$, da Lei Complementar $n^{\circ} 73$, de 10 de fevereiro de 1993.

14 Norma citada no item 02 desta monografia.

15 "X - fixar a interpretação da Constituição, das leis, dos tratados e demais atos normativos, a ser uniformemente seguida pelos órgãos e entidades da Administração Federal;"

16 "XI - unificar a jurisprudência administrativa, garantir a correta aplicação das leis [sem grifo no original], prevenir e dirimir controvérsias entre os órgãos jurídicos da Administração Federal;" 17 "VII - assessorar o Presidente da República em assuntos de natureza jurídica, elaborando pareceres e estudos ou propondo normas, medidas e diretrizes;" 
Por derradeiro, considera-se de suma importância algumas ponderações acerca do inciso $\mathrm{VI}^{18}$, do artigo $4^{\circ}$, em virtude de estarem consignadas neste dispositivo normas que trazem uma necessidade de se aferir caso a caso as ligações entre os interesses da União e os interesses da coletividade. Isso porque, em sua atuação, o Advogado-Geral, atendendo aos interesses da União, deve satisfazer os interesses da coletividade, sob pena de seu desempenho recair, única e exclusivamente, em interesses que, algumas vezes, passam longe dos anseios da coletividade e, lastimavelmente, recaem em interesses secundários, ou seja, dos próprios administradores. A possibilidade de o chefe da Advocacia-Geral da União desistir, transigir, acordar e firmar compromisso nas ações em que haja interesse da União, consubstancia-se em um enorme poder, em virtude da amplitude dos interesses em jogo, o que acaba por demonstrar, igualmente, a imensa magnitude dessa instituição.

\subsection{Notícias sobre a atuação da Advocacia-Geral da União e de seus órgãos} como exemplos práticos de que há viabilidade na busca dos interesses primários

Utilizar-se-ão os exemplos práticos a seguir para que não se permaneça apenas na abstração de uma argumentação, tentando-se, de maneira otimista, fazer com que a atuação de todos os órgãos da Advocacia-Geral da União possa seguir o mesmo norte que está ali propugnado, que é a busca e a concretização dos interesses primários (públicos). Evidenciando-se que a busca por esses interesses é relevante, mas muito mais relevante é a sua efetivação. Diante disso, fazendo-se um exercício exemplificativo, a busca sem a devida concretização é o mesmo que ocorre com um copo sem água em um deserto, porque se não for efetuado um esforço enorme por quem tem a incumbência, buscando-se a água, através de um trabalho abundantemente zeloso e comprometido com a função e a necessidade da utilização daquele objeto, nunca se concretizará a finalidade para a qual o mesmo se destina, vindo a se tornar um instrumento "completamente inerte", que não tem mais razão de existir. Então, para que a busca aos interesses primários seja cada mais efetiva, é necessário, obrigatoriamente, que haja uma real solidificação desses interesses em cada situação. Pois, se assim não for, a busca vai se enfraquecendo paulatinamente, caindo-se na obscuridade do prevalecimento dos interesses secundários.

\section{a) Advocacia-Geral da União edita súmulas que beneficiam contribuintes do INSS e da Receita Federal ${ }^{19}$}

$A b$ initio, é indispensável fazer-se uma rápida explicação do que é uma súmula, enfocando-se o conceito das Súmulas Administrativas editadas pela Advocacia-Geral da União. Pode-se dizer que estas são uma forma de uniformização da jurisprudência dos tribunais, em virtude de decisões em que estes adotam idêntica interpretação a

18 "VI - desistir, transigir, acordar e firmar compromisso nas ações de interesse da União, nos termos da legislação vigente;"

19 Publicada em 01.07.2002. [Internet] www.agu.gov.br 
determinado caso concreto, vindo a serem agilizadas, através das Súmulas Administrativas, as decisões concernentes às mesmas situações no âmbito da Administração Pública Federal.

Passa-se agora à análise da notícia que está disposta neste subtítulo.

A Advocacia-Geral da União editou recentemente as súmulas administrativas de números $17^{20}$ e $18^{21}$, que se referem respectivamente à concessão de Certidão Positiva de Débitos com efeito de Negativa, emitida quando a dívida está sendo paga em parcelas e, Certidão Negativa de Débito (CND). As súmulas permitirão maior rapidez aos advogados públicos, tanto na defesa dos interesses do Instituto Nacional de Seguridade Social (INSS) quanto da Fazenda Nacional. Também beneficiarão os contribuintes que dependem da emissão desses documentos para comprovar que estão recolhendo em dia os tributos devidos ao INSS e à Fazenda Nacional, indispensáveis para contrair empréstimos e participar de licitações públicas, entre outras transações. Essa medida, que vincula todos os órgãos jurídicos da União, autarquias e fundações públicas, conforme a Lei Complementar $n^{\circ} 73 / 93$, tem o escopo de evitar a propositura de novas ações judiciais, cuja matéria já esteja pacificada nos tribunais superiores 22 .

Essas duas súmulas parecem trazer elementos que realmente podem ajudar na efetividade dos interesses primários, pois, no caso das licitações, o certame não será restrito aos poucos que não tenham nenhum débito, mas também àqueles que estejam regularizando sua situação, mediante pagamento parcelado, o que não os impede, muito pelo contrário, de ofertarem a melhor proposta e, por consequiência, executarem com eficiência o objeto do contrato. Isso alarga a "concorrência" entre os licitantes, fazendo com que a administração pública possa conseguir o melhor serviço, pelo melhor preço, atendendo-se ao interesse da coletividade em que a licitação tenha um acesso mais democratizado e, como corolário natural, que a mesma coletividade possa ter satisfeito os seus anseios, desencadeadores daquela licitação, petrificando-se assim os interesses primários.

Com relação à agilização do trabalho dos advogados públicos, no que tange à defesa do INSS e da Fazenda Nacional, em virtude da não interposição de recurso nas situações especificadas nas súmulas aludidas, é de se louvar tal medida, isso porque haverá um importante desafogamento dos tribunais superiores, vindo-se, em certa medida, a dinamizá-los, podendo estes se preocupar com questões que verdadeiramente tenham grande relevo para a administração pública e, sobretudo, para a coletividade.

20 Datada de 19.06.2002. Traça a orientação para que os advogados públicos não recorram das decisões judiciais que determinem a expedição de Certidão Positiva de Débitos com efeito de Negativa, sem que o contribuinte precise apresentar alguma garantia (bem) em contrapartida.

21 Datada de 19.06.2002. Determina que os advogados públicos não recorram das decisões judiciais que estabelecem a concessão da Certidão Negativa de Débito, quando não existir crédito tributário devidamente constituído.

22 A edição de súmulas administrativas é também uma das atribuições do Advogado-Geral da Uniāo, sendo o que dispõe, in verbis, o inciso XII do artigo $4^{\circ}$. da referida Lei Orgânica da Advocacia-Geral: "editar enunciados de súmula administrativa, resultantes de jurisprudência iterativa dos tribunais:" 

seis meses ${ }^{23}$

O último levantamento realizado pelo Departamento de Cálculos e Perícias da Advocacia-Geral da União revelou que, no primeiro semestre deste ano, foi possível impugnar $\mathrm{R} \$ 2,9$ bilhões em cálculos de precatórios superfaturados [sem grifo no original]. Isto significa que este total deixou de sair dos cofres públicos e está sob apreciação judicial quanto à exatidão dos cálculos dos precatórios. $\mathrm{O}$ resultado foi obtido após criteriosa análise e profunda verificação técnica realizada em 17.864 processos judiciais.

No mesmo período, a União foi executada em $\mathrm{R} \$ 4,4$ bilhões. Ao refazer os cálculos destes precatórios, a $A G U$ descobriu que $R \$ 2,9$ bilhões, 66,43\% do total deles, seriam pagos a mais [sem grifo no original]. Por isso, entrou com ações de impugnação para corrigir os cálculos. Os $\mathrm{R} \$ 1,5$ bilhão restantes a União concordou pagar. De 1995 até junho de 2002, foram impugnados $R \$ 21$ bilhões, sendo que apenas no ano passado esse total chegou a $R \$ 3,7$ bilhões. (2002, www.agu.gov.br)

Com esse exemplo verifica-se que, não obstante haver exageros por parte da administração pública na demora no pagamento dos precatórios, é extremamente necessário que sejam pagos os valores monetários corretos, sob pena de se fazer com que o Poder Público despenda valores absurdos e que, evidentemente farão falta para a colocação em prática de inúmeras políticas públicas, o que macula a satisfação dos interesses primários.

Deve-se sempre ter em mente que toda e qualquer quantia em dinheiro que a administração pública paga a mais, sem isso ser devido, torna-se mais um elemento cerceador dos interesses da coletividade e, com certeza, mais uma injustiça no seio social, já que, dessa forma, cada vez menos indivíduos terão seus direitos primordiais satisfeitos. E além disso, a Fazenda Pública, assim como a administração pública como um todo, pertence a todas as pessoas, as quais ainda, em sua grande maioria, infelizmente não têm essa consciência, passando despercebidas algumas circunstâncias corriqueiras que causam perdas aos cofres públicos, portanto, a elas próprias.

c) Procuradoria Regional da União da la Região, órgão da AGU, atua e Justiça decreta arresto dos bens de Luiz Estevão ${ }^{24}$

O Juiz Ricardo Gonçalves da Rocha Castro, da $19^{\mathrm{a}}$ Vara da Justiça Federal do Distrito Federal, decretou o arresto dos bens do Grupo OK - Construções e Incorporações S/A, cujo acionista controlador é Luiz Estevão de Oliveira Neto, acusado de desviar recursos das obras do Tribunal Regional do Trabalho de São Paulo. A ação cautelar de arresto dos bens de Luiz Estevão foi proposta pela Procuradoria Regional da União da $I^{a}$ Região, órgão da AGU. [sem grifo no original] 
A partir desta decisão, os bens de Luiz Estevão são a garantia da ação de execução, que a $A G U$ promoverá nos próximos dias [sem grifo no original], para ressarcimento dos cofres públicos de $\mathrm{R} \$ 251.059 .041,95$, total de recursos desviados, conforme acórdão do Tribunal de Contas da União (TCU). Estes bens estavam indisponíveis por decisão administrativa do TCU, que venceu ontem (22.05). (2002, www.agu.gov.br)

A Advocacia-Geral da União, através de um dos seus órgãos de execução ${ }^{25}$, a Procuradoria Regional da União da $1^{\mathbf{a}}$ Região, está procurando garantir o devido ressarcimento ao erário, fazendo com que os interesses primários, os quais foram tolhidos, mesmo que indiretamente, quando daquele "monstruoso" desvio de verbas públicas do Tribunal Regional do Trabalho de São Paulo, possam ser alcançados. Porém, o mero ressarcimento ao fisco do dinheiro que foi desviado não basta, é preciso que essa quantia, que um dia, espera-se, voltará aos cofres públicos, seja muito bem empregada nas políticas de satisfação das necessidades da coletividade, que não são poucas.

\subsection{Exposição esquemática da atuação da Advocacia-Geral da União na busca incessante dos interesses primários}

Entende-se haver relevância em uma exposição esquemática, ao final desse item, da idéia central de nosso texto, para que a mesma possa ser firmada mais claramente. Não obstante se ter explicitado algumas considerações acerca dos interesses primários (públicos) e dos interesses da União, parece que há necessidade de se aprofundar melhor a relação existente entre estes, que poderiam, de certa maneira, restringir a atuação da Advocacia-Geral da União, e aqueles, dos quais se extrai um conteúdo bem mais abrangente e, até, difícil de se determinar o limite de sua abrangência.

Os interesses da União, considerada como a conjugação das vontades dos Estados-membros com objetivos de interesse comum ${ }^{26}$, pautam a atuação da Advocacia-Geral da União, no sentido de estarem consignados na devida "representação" ao Estado Federal exercida por esta. Manifesto está que jamais a Advocacia-Geral da União irá ou poderá atuar contra os interesses da União, visto que esta é a pessoa jurídica de Direito Público interno que possui grande prevalência nas questões de relevo nacional e internacional. No entanto, não há a exigência de que, buscando-se satisfazer os interesses primários, a atuação da Advocacia-Geral esteja limitada à caracterização dos interesses da União, ou seja, que os interesses da União vinculem a esfera dos interesses primários de tal maneira que estes sejam apenas parcialmente concretizados, não havendo, consequientemente, o pleno colorimento dos interesses da coletividade.

Defende-se ardorosamente o posicionamento de que a Advocacia-Geral deve atuar, de acordo com o princípio da razoabilidade ${ }^{27}$, atendendo aos interesses da

25 Artigo $2^{\circ}$, II, $a$, da Lei Complementar $n^{\circ} 73 / 93$.

26 Definiçāo dada por SILVA, De Plácido e. Vocabulário Jurídico. 17. ed. Rio de Janeiro, Forense, 2000, p. 841.

27 Desenvolvido no item 6 desta monografia. 
União, não aos interesses dos detentores do poder em si, e, exercendo esse mister, evidentemente, posicionando-se na orientação suprema da satisfação dos interesses primários. Por isso, pondera-se que não há qualquer problema se, para satisfazer os interesses primários, a Advocacia-Geral da União "amplie" sua orientação funcional-administrativa. Isso implica na consideração de que os interesses da União têm um âmbito muito menor que o dos interesses públicos (primários), o que coloca estes em um patamar de importância muito maior, visto que, se inobservados, levam as instituições democráticas, como quer ser a Advocacia-Geral da União, à bancarrota.

Essa é, portanto, a explicação que se faz do esquema colocado abaixo, o qual pode, talvez, demonstrar. em um visual mais claro e esmiuçado, o que se tenta elaborar na modesta análise supra.

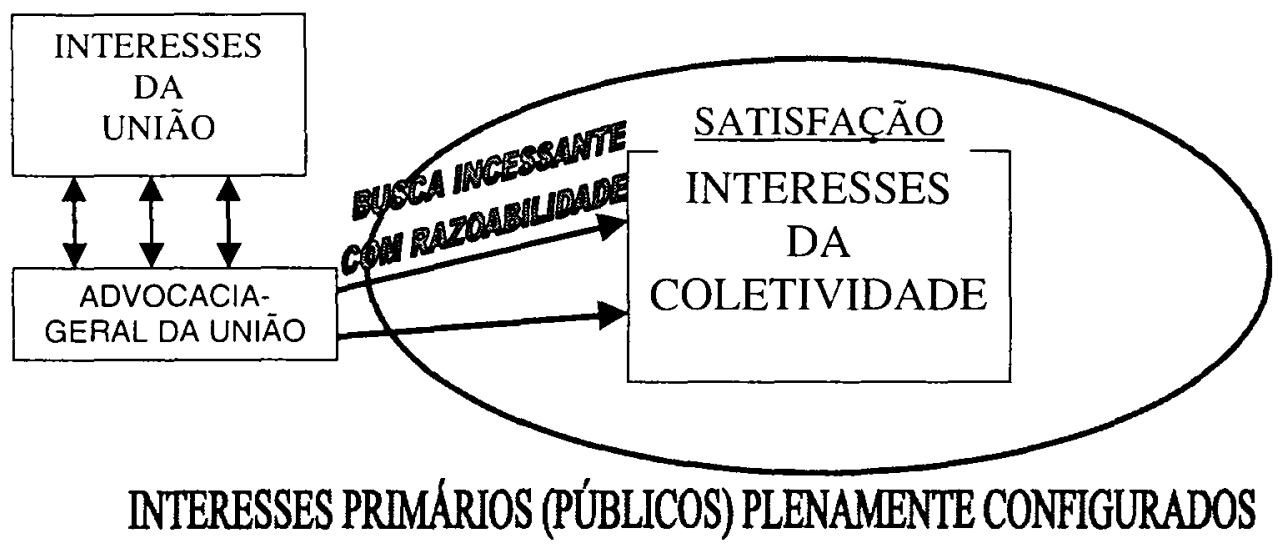

4. A pugna pelo desenvolvimento gradativo da advocacia-geral da união - $u m$ esclarecimento contextual

É importante ressaltar que não se está defendendo uma atuação da AdvocaciaGeral da União idêntica à da instituição do Ministério Público. Como se sabe, trata-se de funções essenciais à justiça que, têm, evidentemente, tarefas constitucionais definidas e distintas.

Entretanto, não foi por mero acaso que o legislador constituinte originário elencou entre a funções essenciais à justiça a Advocacia-Geral da União. Pois há que se considerar que a justiça, e aqui se trata da "justiça pública", deve acompanhar todas as manifestações dos membros da Advocacia-Geral. Refere-se à "justiça pública" em razão de haver uma consistente vinculação com a satisfação dos interesses públicos, quais sejam, os interesses primários. Considera-se que, em se conseguindo satisfazer os interesses primários, estará se concretizando, necessariamente, a justiça para o público, a "justiça pública".

Fazendo-se afirmação referente à Advocacia de Estado (Pública) absolutamente pertinente ao que se está procurando desenvolver, Mário Bernardo Sesta propõe o 
seguinte: "É por essa razão, por ser o interesse do Estado a realização da Justiça, que sua tutela jurídica, tanto no patrocínio judicial, quanto no aconselhamento preventivo, é atividade 'essencial à Justiça'." (SESTA, 1993, p. 193)

Por conseguinte, arrazoa-se por um progresso, uma evolução gradativa do direcionamento das atuações da Advocacia-Geral da União, por intermédio da efetiva caracterização dos interesses públicos em cada situação, o que não é complicado quando há bom senso, levando-se a uma possibilidade concreta de se fazer com que vingue a justiça.

Em interessante argumentação, Derly Barreto e Silva Filho sintetiza o relevante mister exercido pela Advocacia Pública, na qual está compreendida a AdvocaciaGeral da União, asseverando: “[...] a Advocacia Pública, no Estado Democrático de Direito brasileiro, insere-se basicamente no contexto do controle jurídico da função administrativa, acautelando, promovendo e defendendo os interesses públicos sob a ótica da justiça." (SILVA FILHO, 1998, p. 68)

\section{As atividades da Consultoria-Geral da União em face da observância dos interesses primários}

A Consultoria-Geral da União, que é subordinada ao Advogado-Geral da União, está disposta no artigo $10^{28}$ da Lei Complementar $n^{\circ} 73 / 93$, tendo a incumbência de, basicamente, auxiliar aquele, com pareceres e trabalhos jurídicos em geral, no que pertine ao assessoramento jurídico do Presidente da República.

Em decorrência disso, revela-se, de maneira latente, a importância das funções exercidas pela Consultoria-Geral da União, a qual, não obstante estar subordinada ao Advogado-Geral, deve pautar-se pelo norte primordial da busca incessante ao interesse público. E para que se efetive o interesse público, entende-se que os membros da Consultoria-Geral devem atuar com total independência, "restringida" somente, se é que se pode dizer isso, pela efetiva caracterização daquele, o que, em verdade, não se trata de uma restrição, mas sim de uma adequação normal e proporcional à ordem jurídica vigente.

Empregando-se uma interpretação sistemática, entende-se que é aplicável, à atuação dos membros da Consultoria-Geral da União, a atribuição constante no inciso III $^{29}$ do artigo 11 da Lei Complementar $n^{\circ} 73 / 93$, que é uma das atribuições das Consultorias Jurídicas, que também são órgãos de execução da Advocacia-Geral da União. Já que, no assessoramento jurídico ao Presidente da República, os membros

28 “Art. 10. À Consultoria-Geral da União, direta e imediatamente subordinada ao Advogado-Geral da Uniāo, incumbe, principalmente, colaborar com este em seu assessoramento jurídico ao Presidente da República produzindo pareceres, informações e demais trabalhos jurídicos que lhes sejam atribuídos pelo chefe da instituição."

29 "III - fixar a interpretação da Constituição, das leis, dos tratados e dos demais atos normativos a ser uniformemente seguida em suas áreas de atuação e coordenação quando não houver orientação normativa do Advogado-Geral da União;" 
da Consultoria-Geral da União terão que, em não havendo interpretação normatizada pelo Advogado-Geral, interpretar a Lei Maior e a normas infraconstitucionais de acordo com os ditames de justiça, decifrando, em cada caso, qual é a melhor maneira, no seu entender, de se chegar a um grau socialmente satisfatório de garantia do interesse primário.

Isso envolve uma conduta vinculada à ética, mas não uma ética adstrita à parafernália cheia de vícios da política brasileira, e sim a ética que tenha por substrato o bom senso e a equidade. A esse respeito, bem assevera Josaphat Marinho: "A medida de sua atuação encontra-se na lei e no amparo do patrimônio ou do interesse público, e não no arbítrio ou no preconceito dos agentes da Administração." (MARINHO, 1983, p. 15) Permite-se discordar, com a devida venia, de parte da afirmação desse autor, quando o mesmo afirma que a atuação dos membros da advocacia pública deve alinhar-se no "amparo do patrimônio ou do interesse público", porque a atuação desses indivíduos não é em um sentido ou em outro, mas sim na direção da proteção do patrimônio e do interesse públicos. Portanto, trata-se da utilização do que na Morfologia da Língua Portuguesa chama-se de conjunção aditiva $(e)$ e não da alternativa $(o u)$, como foi usado, pela razão de que a atuação de todos os órgãos da Advocacia-Geral da União se pauta pela proteção ao patrimônio público e, especialmente, aos interesses primários (públicos). Visto que estes têm realmente uma amplitude maior, mas o patrimônio não pode ser nunca olvidado, porque quando não se confunde inteiramente com o interesse primário em determinado caso, é, necessariamente, uma das arestas deste.

Muitas vezes os pareceres elaborados pelos Consultores são "ignorados”, literalmente engavetados, não obstante estarem arraigados com preceitos de justiça, levando-se ao sobrepujamento de decisões meramente políticas em relação a pareceres fundamentadamente constitucionais, que aperfeiçoariam aquelas, aproximando-as dos interesses primários. Acerca desse ponto, Adelmo Fioranelli Júnior pondera:

[...], a boa ética do Consultor não se coaduna com a atitude de indiferença quanto ao destino dado pela Administração a seus pareceres. Não lhe sendo possivel pretextar que a tarefa jurídica se esgota onde começa a decisão política, a defesa dos interesses públicos posta a seu cargo demanda um grau acentuado de afeição à solução proposta, cujo atendimento deve ser por ele perseguido [sem grifo no original]. (Op. cit., p. 251)

Ainda utilizando interpretação sistemática, pugna-se pelo exercício da atribuição constante no inciso $\mathrm{V}^{30}$ do artigo 11, da Lei da Advocacia-Geral da União, pelos membros da Consultoria-Geral da União, de modo que a legalidade administrativa seja controlada com vistas à orientação extraída da busca pelos interesses primários.

30 " $\mathrm{V}$ - assistir a autoridade assessorada no controle interno da legalidade administrativa [sem grifo no original] dos atos a serem por ela praticados ou já efetivados, e daqueles oriundos de órgão ou entidade sob sua coordenação jurídica;" 
Isso significa que, se houver um comprometimento com as questões inerentes aos interesses públicos, certamente a legalidade interna no âmbito da Advocacia-Geral da União será observada, em decorrência da presunção, juris tantum é verdade, de que quando se age dentro da legalidade, torna-se mais claramente aferível e exequiível o interesse da coletividade. Efetuando uma brilhante assertiva, Derly Barreto e Silva Filho compartilha com a idéia suscitada neste estudo:

[...], na medida em que a Carta política reservou, em caráter privativo, à Advocacia Pública, a atividade de consultoria jurídica, é porque quis que órgão diverso daquele que emite a vontade político-estatal verificasse e garantisse a existência de sintonia formal e material do ato (ou do projeto de ato) aos cânones da justiça, síntese da legalidade, legitimidade e licitude, acautelando, promovendo e defendendo o interesse público. (Op. cit., p. 68)

\subsection{Uma breve análise de pareceres da Consultoria-Geral da União que se consolidaram como jurisprudência administrativa}

Faz-se tempestiva a aferição de alguns pareceres elaborados por Consultores da União de diferentes períodos, para que se possa ter uma visão, mesmo que genérica, do que se tem firmado, em termos de adequação ou não ao interesse público, na jurisprudência administrativa brasileira, que é tão relevante quanto a jurisprudência dos tribunais, porque tem o condão de, quando aprovado o parecer pelo Presidente da República, vincular a Administração Pública Federal em todas as suas esferas ${ }^{31}$.

Evidentemente, como o próprio subtítulo já diz, fez-se uma aferição não tão profunda de alguns dos pareceres da Consultoria-Geral da União, em decorrência do que se propõe neste estudo, ficando este item como uma breve notícia da visão que se teve pela leitura daqueles e não como um marco pacífico de seu contexto geral, pois, como já dito, a especificidade do tema abordado não permite maiores detalhamentos e avaliações.

Sem maiores delongas, o que chama a atenção, a priori, como não poderia deixar de ser diferente, é o fino trato no que se refere à técnica discursiva $\mathrm{e}$ à forma de exposição das razões de fato e de direito nos pareceres lidos ${ }^{32}$.

Pode-se notar que em pelo menos $60 \%$ dos pareceres analisados há realmente a busca ao interesse público, de acordo com cada caso concreto estudado. Isso pode servir de parâmetro para que se tenha uma idéia de como está sendo conduzido o trabalho de consultoria da Advocacia-Geral da União, porém, é lógico que se considera relativa essa dedução. Mesmo porque para ter-se uma idéia absoluta sobre tal condução, teria que ser feita uma análise de todos os pareceres realizados, o que,

31 Conforme o parágrafo $1^{\circ}$ do artigo 40 da Lei Complementar $n^{\circ} 73 / 93$, que dispõe o seguinte: "O parecer aprovado e publicado juntamente com o despacho presidencial vincula a Administração Federal, cujos órgãos e entidades ficam obrigados a lhe dar fiel cumprimento."

32 Pareceres: GQ 101/96, GQ 106/96, GQ 145/98, GQ 151/98, GQ 158/98, GQ 161/98, GQ 183/98, GQ 196/99 e GQ 197/99. (Fonte: Revistas de Direito Administrativo) 
neste momento, é impossível, devido à escassez do tempo e à carência de acesso à grande maioria dos pareceres.

Espera-se que todos os pareceres da Consultoria-Geral da União que estejam alicerçados nas bases fortes dos interesses públicos possam ser aprovados pelo Advogado-Geral, que tem o poder de ditar a orientação da atuação da instituição, vinculando toda a administração pública federal, quando aprovados pelo Presidente da República. E os pareceres desvinculados da busca ao interesse público precisam ser expurgados do ordenamento jurídico, para que não se mantenham "verdades jurídicas" destituidas dos valores da justiça, que, em verdade, estão arraigadas a interesses secundários.

Então, pode-se dizer que a atuação engajada com o interesse público por parte dos consultores da União é importante, entretanto, se não houver a mesma concatenação de ideais, que em verdade são deveres, em relação ao Advogado-Geral e ao Presidente da República, a atividade de feitura dos pareceres por parte dos consultores torna-se "letra morta", fazendo sucumbir a relevância de tais servidores.

Logicamente, sempre haverá de ter uma grande cooperação entre os órgãos supracitados, não no sentido de inexistência de divergências, que são comuns e necessárias, mas sim no sentido de buscar-se, em conformidade com o princípio da razoabilidade, a satisfação do interesse público, que é o fim maior dos órgãos estatais, para ocorrer, deste modo, o colorimento da justiça.

Por ser, a tarefa dos consultores, uma atividade “de início”, já que necessita da aprovação de órgão superior, faz-se mister a consciência de que estão atuando com bom senso, perseguindo sempre a melhor solução para o caso concreto, ou seja, aquela que abarque o interesse da União como corolário natural do atingimento do interesse público, que é mais amplo e buscado de maneira primordial.

Para finalizar, ilustrando o que foi dito acima, de que nem todos os pareceres analisados atendem ao interesse público, cita-se o Parecer $n^{\circ} \mathrm{GQ}-158$, elaborado pelo Consultor da União Luiz Alberto da Silva ${ }^{33}$, no qual argumenta-se sobre a possibilidade de transferência voluntária de recursos públicos em período eleitoral aos candidatos que já estão no governo durante os três meses que antecedem a nova eleição. O Consultor considera ilegal essa prática, estando, evidentemente, correto, segundo o que dispõe o artigo 73 da Lei ${ }^{\circ}$ 9.504/97. Porém, considera legal, com o que se discorda, a confecção de atos preparatórios necessários ao início de uma obra ou serviço, durante o período de três meses, incluindo-se a assinatura de convênio, acordo ou qualquer outro instrumento semelhante, concluindo que esse tipo de ato não afeta a igualdade de oportunidades entre os candidatos, já que essa conduta não é proibida pela Lei 9.504/97. Parece equivocado o entendimento do eminente Consultor, porque mesmo que se considerem como rol taxativo as condutas elencadas no artigo 73 da aludida lei, pode ser aplicada uma interpretação teleológica ao caso concreto, levando-se em conta o bom senso, para que a estrita observância da lei, interpretada literalmente, não faça afastar o interesse público. Então, é ilegítima, pois atenta contra o próprio Estado de Direito, a possibilidade de serem

33 Revista de Direito Administrativo, 213, jul./set., 1998, p. 269. 
celebrados atos preparatórios de uma obra ou serviço (convênios, acordos etc.) no período de três meses anterior à eleição, em razão de haver favorecimento promocional ao candidato do governo, que através do uso da "máquina administrativa" faz falecer o princípio da isonomia, afastando-se completamente o interesse público consistente na existência absoluta de igualdade de oportunidades entre os candidatos. Em suma, o que se está afirmando é que, embora não haja transferência de recursos públicos neste caso, haverá a promoção pessoal do candidato da situação, maculando-se o caráter igualitário que toda disputa por um cargo público demanda, fazendo-se florescerem interesses secundários inicialmente ocultos.

\section{A razoabilidade na atuação da Advocacia-Geral da União - vista sob a ótica do interesse público}

Não poderia ser deixada sem uma aferição, ainda que breve, a razoabilidade no âmbito da Advocacia-Geral da União. Procura-se analisar, portanto, a necessidade da observância incontinenti, ou seja, desde o primeiro momento, do princípio da razoabilidade dentro de sua atuação.

Entende-se que, a partir do instante em que a atuação daquela instituição se regula pela base sólida do princípio da razoabilidade, de acordo com a ordem jurídica, em face de um interesse da União, o interesse público pode ser atingido mais facilmente, visto que uma atuação inquinada de "radicalidade" na defesa de interesse da União pode levar à completa sucumbência do interesse público. Evidentemente, uma atuação desprovida de contornos razoáveis pode levar, fatalmente, em qualquer situação, ao aperfeiçoamento de injustiças.

Atuar com razoabilidade em toda a situação que envolva interesse da União, que é a incumbência da Advocacia-Geral da União, torna-se um dever intrínseco de todos os membros desta, o que a leva, sem desobedecer à lei e nem fugir de suas atribuiçōes, à concretização do interesse público, que é o interesse primário já referido alhures.

Mesmo que o princípio da razoabilidade não esteja, em muitos casos, sendo observado pelos legisladores pátrios quando da elaboração das leis, ainda resta a possibilidade, que se configura em verdadeiro dever, do operador jurídico em observá-lo, atingindo-se assim os "interesses maiores" que dão razão à existência daquelas.

O autor Celso Ribeiro Bastos explica a relevância da razoabilidade para a ciência jurídica, dizendo que os atos do operador jurídico, em geral, devem guardar "no seu conteúdo uma decisão razoável entre as razões que os ditaram e os fins que se procura atingir [sem grifo no original]." (BASTOS, 1996, p. 46) Completando ainda que o Direito "é um instrumento que requer fundamentalmente a razoabilidade." (Op. cit., p. 46)

Destarte, percebe-se que o princípio da razoabilidade é observado quando a atuação da Advocacia-Geral da União efetiva o acolhimento a uma adequada proporção entre os meios aplicados e a finalidade que o ordenamento jurídico visa alcançar. 
Cabendo-se destacar que não é dada à instituição sob análise, nem a qualquer outra, uma persecução desenfreada, "ilimitadamente irresponsável”, ao atingimento do interesse público em cada situação, essa busca deve ser adequadamente processada. Isso significa que o interesse da União, se buscado com razoabilidade leva a uma maior chance de satisfazer o interesse público, cuja satisfação pode proceder-se de várias maneiras, tanto ativas quanto passivas. Já que, dependendo do caso concreto, os membros da Advocacia-Geral, da parte do contencioso ou de consultoria, não importa, podem atuar ou deixar de atuar (se permitido pela lei), de forma razoável, chegando, desse jeito, à clara concretização do interesse público.

Nessa esteira, torna-se interessante até afirmar-se que é quase impossível alcançar-se o degrau do interesse público, que se encontra em um dos mais altos pontos da escada estipulada pelo Direito Administrativo, se for olvidado e, conseqüentemente, inaplicado o princípio da razoabilidade, apresentando-se este como o ponto de partida para a satisfação daquele.

O mestre Hely Lopes Meirelles ${ }^{34}$ assevera, com muita primazia, que o princípio sob comento pode ser tido como o "princípio da proibição do excesso", no que the assiste total razão. Deste modo, considera-se não haver equívoco em se poder denominar o princípio da razoabilidade, pelo que se propõe neste estudo, de princípio da "consciência funcional buscadora do interesse público", pois o agir dos membros da Advocacia-Geral da União deve estar equilibrado entre a consciência da função que lhes é atribuída pela lei e a responsabilidade social extremamente necessária para que se efetive o interesse público.

\section{Conclusäo}

Por toda a aferição que foi realizada, pode-se dizer que a atuação da Advocacia-Geral da União demanda, nos dias de hoje, um grande comprometimento com os interesses primários, já que nenhum órgão estatal está eximido dessa busca. Isso significa que sempre haverá uma situação em que a atuação de qualquer membro daquela instituição pode implicar na satisfação ou no afastamento dos interesses primários.

Em razão disso, visando satisfazer o interesse público, que é sinônimo de interesse primário, deve haver uma adequada proporção entre os meios possíveis de serem utilizados e os fins maiores que se procura atingir, que nada mais é do que a aplicação prática do princípio da razoabilidade. Princípio este que é elementar para a observância e a efetiva caracterização dos princípios da supremacia e da indisponibilidade do interesse público, que, conforme se nota, foram usados de forma combinada no presente estudo.

A satisfação do interesse primário, fim maior do Estado, necessita obter, de maneira acabada, um "concreto aliado", que se reputa seja a Advocacia-Geral da União, cuja atuação tem enorme prevalência na ordem jurídica vigente. Desse modo,

.4 Direito Administrativo Brasileiro. 27. ed. São Paulo, Malheiros, 2002, p. 91. 
essa instituição se tornará um verdadeiro instrumento para a concretização do interesse público. É facilmente inteligível essa concepção de instrumento, em virtude do grande relevo existente na representação da União, que consiste na curadoria de seus interesses. Contudo, estes não podem dissociar-se dos interesses primários, pois, se houver a dissociação, a Advocacia-Geral da União terá desatendido a sua própria razão de existir como função essencial à justiça, configurada na Constituição da República de 1988.

Considera-se perfeitamente crível a afirmação de que o fortalecimento das instituições estatais em um Estado de Direito está bastante atrelado ao desempenho de suas funções com o devido bom senso, sem desviar de suas atribuições, para que, em qualquer situação, possa chegar-se ao critério mais justo. Essa ponderação também cabe à instituição da Advocacia-Geral da União, cuja tarefa deve ser desempenhada de acordo com os fins a que está adstrito o Estado, sem olvidar-se da necessária razoabilidade em qualquer caso.

A Advocacia-Geral da União, em decorrência da magnitude de sua atuação, é, de certa forma, um dos "órgãos chave" para a efetividade dos interesses primários, visto que interferir diretamente na orientação das decisões de um dos Poderes da União, o Executivo, consubstancia-se como uma atribuição extremamente relevante para todo o conjunto social.

Tem-se a expectativa de que um dia as incursões meramente políticas e, portanto, maléficas, possam ser afastadas dos meandros das instituições essenciais à justiça, conseguindo-se assim que uma "simples" atuação com razoabilidade e que visa $o$ atendimento ao interesse público possa satisfazer aos anseios da coletividade brasileira.

Pugna-se por um crescimento da noção de responsabilidade para com os interesses primários no âmbito da Advocacia-Geral da União, o que não é nenhum contra-senso, haja vista a relevância dos interesses em jogo e necessidade latente da sociedade em que sejam efetivamente realizados os seus interesses.

Para finalizar, deve-se ter em mente que, não obstante haver uma Magna Carta "Cidadã" em nosso país, ainda se está lutando pelo aperfeiçoamento das atividades do Poder Público e pela solidificação da justiça em todos os setores da coletividade.

\section{BIBLIOGRAFIA ${ }^{35}$}

ARAÚJO, Edimir Netto de. - Procedimentos administrativos para proteção do patrimônio público. Ponta Grossa, PR, Centro de Ensino Superior dos Campos Gerais - CESCAGE, Faculdade de Direito, Aporia Jurídica, ano I, 01, jul./dez., 2000.

ÁVILA, Humberto Bergmann. - Repensando o "princípio da supremacia do interesse público sobre o particular". Revista Trimestral de Direito Público, São Paulo, Malheiros, 24, 1998.

35 Ao final estão inseridas as ementas de todos os pareceres da Advocacia-Geral da Uniāo estudados para a elaboração desta monografia. 
BARRAL, Welber. - A monografia no curso de direito: algumas considerações. Ponta Grossa, PR, Centro de Ensino Superior dos Campos Gerais - CESCAGE, Faculdade de Direito, Aporia Jurídica, ano I, 01, jul./dez., 2000.

BARROSO, Luís Roberto. - Interpretação e aplicação da Constituição: fundamentos de uma dogmática constitucional transformadora. 3. ed. São Paulo, Saraiva, 1999.

BASTOS, Celso Ribeiro. - Curso de direito administrativo. 2. ed. São Paulo, Saraiva, 1996.

BASTOS, Celso Ribeiro; MARTINS, Ives Gandra. - Comentários à Constituição do Brasil: promulgada em 5 de outubro de 1988. v. 4. São Paulo, Saraiva, 1997. BEZNOS, Clovis. - A Procuradoria Geral do Estado e a defesa dos interesses públicos. Revista da Procuradoria Geral do Estado de São Paulo, 31, jun., 1989.

BLANCHET, Luiz Alberto. - Curso de Direito Administrativo. Curitiba, Juruá, 1998.

BORGES, Alice Gonzalez. - Interesse público: um conceito a determinar. Rio de Janeiro, Revista de Direito Administrativo, 205, jul./set, 1996.

BULOS, Uadi Lammêgo. - Constituição Federal anotada: jurisprudência e legislação infraconstitucional em vigor. São Paulo, Saraiva, 2000.

CASTRO, Aldemario Araujo. - Uma proposta de reestruturação da AdvocaciaGeral da União. Disponível em: http://wwwl.jus.com.br/doutrina/texto.asp?id=308 Acesso em: 16 de agosto de 2002.

COCCARO FILHO, Celso Augusto. - Advocacia Pública e Moralidade Administrativa. Advocacia Pública \& Sociedade, São Paulo, Max Limonad, 1998, p. 21. Disponível em: http://www.ibap.org/artigos/cacf01.htm Acesso em: 23 de agosto de 2002.

COMPARATO, Fábio Konder. - Ensaio sobre o juízo de constitucionalidade de políticas públicas. Revista dos Tribunais, ano 86, 737, mar., 1997.

. - Juizes independentes ou funcionários subordinados? Cidadania e Justiça, ano 2, 04, $1^{\circ}$ semestre, 1998.

COSTA, Alexandre Araújo. - O princípio da razoabilidade na jurisprudência do Supremo Tribunal Federal. Brasília, Notícia do Direito Brasileiro (nova série), 07, UnB, Faculdade de Direito, 2000.

COUTINHO, Jacinto Nelson de Miranda. - O procurador de estado e o pensamento jusfilosófico. Revista da Procuradoria Geral do Estado de São Paulo, 44, dez., 1995.

COUTO, Sérgio. - A AGU e os motivos nobres. Disponível em: http://www advogadopublico.hpg.ig.com.br/doutrina/aagueosmotivosnobres.htm Acesso em: 17 de agosto de 2002.

DI PIETRO, Maria Sylvia Zanella. - Direito Administrativo. 14. ed. São Paulo, Atlas, 2002.

FARIA, Ana Paula Andrade Borges de; FERREIRA, Olavo Augusto Vianna Alves. - A independência e a autonomia funcional do Procurador do estado. Disponivel em: http://www.advogadopublico.hpg.ig.com.br/doutrina/independencia. htm Acesso em: 05 de julho de 2002. 
FERREIRA FILHO, Manoel Gonçalves. - O Estado no limiar do novo século. Rio de Janeiro, Revista de Direito Administrativo, 217, jul./set., 1999.

FIGUEIREDO, Guilherme José Purvin de; BARROS, Marcos Ribeiro de. - $O$ advogado público nas Ações Diretas de Inconstitucionalidade. Disponível em: http://members.tripod.com/ ibap/artigos/mrbgjpfl.htm Acesso em: 12 de julho de 2002.

FIGUEIREDO, Lúcia Valle. - Curso de Direito Administrativo. 2. ed., São Paulo, Malheiros, 1995.

FIORANELLI JÚNIOR, Adelmo. - A procuradoria geral do estado como função essencial à justiça. Revista da Procuradoria Geral do Estado de São Paulo, 40, dez., 1993.

FRISSO, Giovana Maria. - A busca da justiça no Estado de Direito. Brasília, Notícia do Direito Brasileiro (nova série), 07, UnB, Faculdade de Direito, 2000.

GALUPPO, Marcelo Campos. - Os princípios jurídicos no Estado Democrático de Direito: ensaio sobre o modo de sua aplicação. Brasília, Revista de Informação Legislativa, ano 36, 143, jul./set., 1999.

GASPARINI, Diógenes. - Direito Administrativo. 4. ed. São Paulo, Saraiva, 1995. GRUPO DE ESTUDOS DA ABDConst. — Solução de Conflitos entre Princípios. Curitiba, PR, Revista da Academia Brasileira de Direito Constitucional, v. 01, 01, 2001.

GUALAZZI, Eduardo Lobo Botelho. - Advocacia pública e direito comparado. Revista da Procuradoria Geral do Estado de São Paulo, 30, dez., 1988.

GUSMÃO, Paulo Dourado de. - Introdução ao Estudo do Direito. 23. ed. Rio de Janeiro, Forense, 1998.

HERKENHOFF, João Baptista. - Justiça, direito do povo. 2. ed. Rio de Janeiro, Thex Editora, 2002.

JUSTEN FILHO, Marçal. - Conceito de interesse público e a "personalização" do direito administrativo. Revista Trimestral de Direito Público, São Paulo, Malheiros, 26, 1999.

KOURY, Suzy Elizabeth Cavalcante. - A ética no serviço público. Rio de Janeiro, Revista de Direito Administrativo, 220, abr./jun., 2000.

MAQUIAVEL, Nicolau. - O Príncipe. [tradução: Maria Lucia Cumo] 8. ed. Rio de Janeiro, Paz e Terra, 2002.

MARINHO, Josaphat. - Advocacia Pública. Revista da Procuradoria Geral do Estado de São Paulo, 21, dez., 1983.

MARTINS FILHO, Ives Gandra da Silva. - O princípio ético do bem comum e a concepção jurídica do interesse público. Disponível em: http://wwwl.jus. com.br/doutrina/texto.asp?id=11 Acesso em: 05 de julho de 2002.

MASSA, Patricia Helena. - O papel do advogado público na Administraçāo democrática e o controle da legalidade. Revista da Procuradoria Geral do Estado de São Paulo, 47/48, jan./dez., 1997, p. 115. Disponível em: http://www.pge.sp.gov.br/centrodeestudos/revistaspge/revista3/rev7.htm Acesso em 06 de julho de 2002.

MEIRELLES, Hely Lopes. - Direito Administrativo Brasileiro. 27. ed. São Paulo, Malheiros, 2002. 
MELLO, Celso Antônio Bandeira de. - Curso de Direito Administrativo. 11. ed. São Paulo, Malheiros, 1999.

- - Regulamentação profissional - princípio da razoabilidade - desvio de poder (Parecer). Rio de Janeiro, Revista de Direito Administrativo, 204, abr./jun., 1996, p. 333/352.

MELlO, Marco Aurélio Mendes de Farias. - Judiciário: do caos à ordem. Disponivel em:http://www.stf.gov.br/noticias/imprensa/palavra_dos ministros/ler. asp?CODIGO=22628\&tip=AR Acesso em:13 de julho de 2002.

MOREIRA NETO, Diogo de Figueiredo. - As funções essenciais à justiça e as procuraturas constitucionais. Revista da Procuradoria Geral do Estado de São Paulo, 36, dez., 1991.

- Uma nova administração pública. Rio de Janeiro, Revista de Direito Administrativo, 220, abr./jun., 2000.

NETTO, Agostinho do Nascimento. - Acesso à justiça: uma proposta. Disponível em: http://www.agostinhonetto.hpg.ig.com.br/acesso.htm Acesso em: 19 de julho de 2002.

OLIVEIRA, Eva Aparecida de. - A que vem a lógica jurídica? Jataí, GO, Revista Jurídica do Centro de Ensino Superior de Jataí - CESUT, ano I, 01, $1^{\circ}$ semestre, 2000.

OMMATI, Fides Angélica. - Advocacia pública - algumas reflexões. Disponível em: http://wwwl.jus.com.br/doutrina/texto.asp?id=2111 Acesso em: 20 de julho de 2002.

OSÓRIO, Fábio Medina. - Existe uma supremacia do interesse público sobre o privado no direito administrativo brasileiro? Rio de Janeiro, Revista de Direito Administrativo, 220, abr./jun., 2000.

PELLEGRINO, Carlos Roberto M.. - Concepção jurídica de povo (Estado do povo ou o povo do Estado?). Brasília, Revista de Informação Legislativa, ano 37, 148, out./dez., 2000.

PEREIRA, Caio Mario da Silva. - A Advocacia do Estado. Revista da Procuradoria Geral do Estado de São Paulo, 10, jun.,1977.

PEREIRA, José Matias. - Repensando a administração pública: o futuro do Estado de bem-estar. Brasília, Revista de Informação Legislativa, ano 36, 142, abr./jun., 1999.

QUINTÃO, Geraldo Magela da Cruz. - Defesa do interesse público na Constituição Federal - Advocacia de Estado - Função essencial à justiça. Disponível em: http://www.idp.org.br/dipcf.htm Acesso em: 06 de julho de 2002.

REALE, Miguel. - Lições preliminares de direito. 16. ed. São Paulo, Saraiva, 1988. RODRIGUES, Anadyr Mendonça. - A atuação conjunta da Advocacia-Geral da União e dos órgãos vinculados. Revista da AGU, ano II, 06, jan., 2001. Disponível em: http://www.agu.gov.br/ce/cenovo/ce.asp?mnu=3_2\&num=6 Acesso em: 05 de julho de 2002.

SESTA, Mário Bernardo. - Advocacia do Estado: Posição Institucional. Brasília, Revista de Informação Legislativa, ano 30, 117, jan./mar., 1993.

SILVA, De Plácido e. - Vocabulário Jurídico. 17. ed. Rio de Janeiro, Forense, 2000 . 
SILVA, José Afonso da. - Curso de Direito Constitucional Positivo. 19. ed. São Paulo, Malheiros, 2001.

SILVA FILHO, Derly Barreto e. - $O$ controle da legalidade diante da remoção e da inamovibilidade dos advogados públicos. Brasília, Revista de Informação Legislativa, ano 35, 140, out./dez., 1998.

SOUTO, João Carlos. - Dershowitz e a Advocacia-Geral da União. Revista da AGU, ano II, 07, fev., 2001. Disponível em: http://www.agu.gov.br/ce/cenovo/ce.asp?mnu=3_2\&num=7 Acesso em: 12 de julho de 2002.

TÁCITO, Caio. - Perspectivas do direito administrativo no próximo milênio. Rio de Janeiro, Revista de Direito Administrativo, 212, abr./jun., 1998.

- - A razoabilidade das leis. Rio de Janeiro, Revista de Direito Administrativo, 204, abr./jun., 1996.

- - A reforma do estado e a modernidade administrativa. Rio de Janeiro, Revista de Direito Administrativo, 215, jan./mar., 1999.

ZYMLER, Benjamin. - Política, Direito e reforma do Estado: uma visão funcional-sistêmica. Brasília, Revista de Informação Legislativa, ano 37, 147, jul./set., 2000.

\section{Jurisprudência administrativa consultada}

Parecer - GQ 101/96 - Advocacia-Geral da União - EMENTA: Compensação de créditos de natureza não tributária autorizada por lei especial. A lei nova, que estabeleça normas gerais ou especiais a par das já existentes, não revoga a lei anterior (Lei de Introdução ao Código Civil, art. $2^{\circ}$, parágrafo $2^{\circ}$ ). Aplicação da norma especial em detrimento da norma geral, nos estritos termos por aquela enunciados. (Rio de Janeiro, RDA, 204, abr./jun., 1996, p. 301.)

Parecer - GQ 106/96 - Advocacia-Geral da União - EMENTA: A readmissão, versada no parágrafo $5^{\circ}$ do artigo $8^{\circ}$ do ADCT, aplica-se a todos quantos, no período compreendido entre 1979 e 5 de outubro de 1988, foram demitidos comprovadamente pelos motivos especificados nesse preceito, sendo irrelevante que o empregador tenha imprimido à dispensa fictícia conotação de sem justa causa. (Rio de Janeiro, RDA, 205, jul./set., 1996, p. 283.)

Parecer - GQ 145/98 - Advocacia-Geral da Uniäo - EMENTA: Ilícita a acumulação de dois cargos ou empregos de que decorra a sujeição do servidor a regimes de trabalho que perfaçam o total de oitenta horas semanais, pois não se considera atendido, em tais casos, o requisito da compatibilidade de horários. Com a superveniência da Lei $n^{\circ} 9.527$, de 1997, não mais se efetua a restituição de estipêndios auferidos no período em que o servidor tiver acumulado cargos, empregos e funções públicas em desacordo com as exceções constitucionais permissivas e de má fé. (Rio de Janeiro, RDA, 212, abr./jun., 1998, p. 259.)

Parecer - GQ 151/98 - Advocacia-Geral da União - EMENTA: É contado, para fins de reconhecimento do direito à estabilidade concedida pelo art. 19 do Ato das Disposições Constitucionais Transitórias, relativo à Constituição de 1988, o tempo de serviço prestado continuamente, em mais de um cargo ou emprego, 
incluído o serviço militar profissional, pelo servidor civil que, em 5 de outubro de 1988, preencha as condições estabelecidas nesse preceito. (Rio de Janeiro, RDA, 212, abr./jun., 1998, p. 270.)

Parecer - GQ 158/98 - Advocacia-Geral da União - EMENTA: 1) Interpretação do art. 73, inciso VI, da Lei $\mathrm{n}^{\circ} 9.504$, de 30 de setembro de 1997, em confronto com o art. 82 da Lei $\mathrm{n}^{\circ} 9.100$, de 29 de setembro de 1995. 2) O Conceito de transferência voluntária de recurso. 3) Manutenção do entendimento exarado no Parecer $n^{\circ}$ AGU/LA-02/96, sobre o conceito de obra em andamento. 4) O caráter taxativo do elenco de condutas previsto no art. 73 da lei $n^{\circ} 9.504 / 97$. 5) A não proibição da prática de atos preparatórios, inclusive a formalização de convênios, acordos ou instrumentos congêneres. (Rio de Janeiro, RDA, 213, jul./set., 1998, p. 269.)

Parecer - GQ 161/98 - Advocacia-Geral da União - EMENTA: A Lei n 8.112, de 1990, não desautoriza a orientação até agora observada de que as quantias recebidas "indevidamente", de boa fé, em virtude de errônea interpretação da lei pela Administração e posterior mudança de critério Jurídico adotado, não precisam ser repostas, mesmo quando desconstituído o ato. Conceito de pagamento indevido. Os pagamentos feitos em consequência de liminares, posteriormente cassadas por decisões judiciais definitivas, são pagamentos indevidos e estão sujeitos à reposição, uma vez que não se enquadram na orientação adotada pela AGU. (Rio de Janeiro, RDA, 213, jul./set., 1998, p. 274.)

Parecer - GQ 183/98 - Advocacia-Geral da União - EMENTA: É compulsória a aplicação da penalidade expulsiva, se caracterizada infração disciplinar antevista no art. 132 da Lei $n^{\circ} 8.112$, de 1990. (Rio de Janeiro, RDA, 215, jan./mar., 1999, p. 285.)

Parecer - GQ 196/99 - Advocacia-Geral da União - EMENTA: O servidor empossado em cargo público é automaticamente submetido a estágio probatório na data em que entra em exercício, conseqüente da nomeação, e sua avaliação e confirmação, se for o caso, são efetuadas por ato unilateral da Administração (arts. 20 e 29 da Lei $n^{\circ} 8.112$, de 1990), não assistindo ao estágio direito de ser exonerado, a pedido, e reconduzido ao cargo inacumulável de que se afastou, em decorrência da posse. (Rio de Janeiro, RDA, 217, jul./set., 1999, p. 219.)

Parecer - GQ 197/99 - Advocacia-Geral da União - EMENTA: O adicional por tempo de serviço e a gratificação de atividade executiva são calculados sobre o vencimento-básico que, para esse fim, absorve a representação mensal, nos termos do art. $1^{\circ}$, parágrafo $1^{\circ}$, do Decreto-lei $n^{\circ} 2.333$, de 1987. (Rio de Janeiro, RDA, 217, jul./set., 1999, p. 225.) 